\title{
Thermo-catalytic degradation of PE and UHMWPE over zeolites with different pore systems and textural properties
}

\section{(Degradação termocatalítica de PE e UHMWPE sobre zeólitas com diferentes sistemas de poros e propriedades texturais)}

\author{
B. J. B. Silva ${ }^{1 *}$, A. C. S. Melo', D. S. Silva ${ }^{1}$, L. V. Sousa ${ }^{1}$, P. H. L. Quintela ${ }^{2}$, S. L. Alencar ${ }^{1}$, A. O. S. Silva ${ }^{1}$ \\ ${ }^{1}$ Federal University of Alagoas, Department of Chemical Engineering, Laboratory of Catalysts Synthesis, \\ 57072-900, Maceió, AL, Brazil \\ ${ }^{2}$ Federal University of Sergipe, Department of Chemical Engineering, São Cristóvão, SE, Brazil
}

\begin{abstract}
The thermo-catalytic degradation of polyethylene (PE) and ultra-high molecular weight polyethylene (UHMWPE) was studied in the presence of zeolites (ZSM-5, ZSM-22, and ferrierite) with different pore systems and textural properties. The zeolites were physically mixed with polymers in the proportion of $30 \mathrm{wt} \%$ and submitted to thermogravimetric analysis at heating rates of 5,10 , 20 , and $30{ }^{\circ} \mathrm{C} \cdot \mathrm{min}^{-1}$. The activation energy of the degradation process was determined using the Flynn-Wall-Ozawa method. The addition of zeolites to polymers has considerably reduced the temperature of degradation. ZSM-22 demonstrated greater efficiency in the degradation of PE because it has a smaller crystallite size, promoting a shorter diffusional path for the polymer fragments coming from the surface. Ferrierite showed a lower energy level in the degradation of UHMWPE, showing the need for synergy between the accessibility of the structure and acidity of the catalyst to promote the cracking of this polymer.
\end{abstract}

Keywords: thermo-catalytic degradation, polymers, zeolite, Flynn-Wall-Ozawa method.

\section{Resumo}

A degradação termocatalítica do polietileno (PE) e do polietileno de ultra alto peso molecular (UHMWPE) foi estudada na presença de zeólitas (ZSM-5, ZSM-22 e ferrierita) com diferentes sistemas de poros e propriedades texturais. As zeólitas foram misturadas fisicamente aos polímeros na proporção de $30 \%$ em massa e submetidas à análise termogravimétrica nas taxas de aquecimento de 5 , 10,20 e $30^{\circ} \mathrm{C} . \mathrm{min}^{-1}$. A energia de ativação do processo de degradação foi determinada pelo método de Flynn-Wall-Ozawa. A adição das zeólitas aos polímeros reduziu consideravelmente a temperatura de degradação. A ZSM-22 demonstrou maior eficiência na degradação do PE por apresentar menor tamanho de cristalito, promovendo um caminho difusional mais curto para os fragmentos de polímero provenientes da superfície. A ferrierita apresentou menor nível de energia na degradação do UHMWPE, mostrando a necessidade da sinergia entre a acessibilidade da estrutura e a acidez do catalisador para promover a quebra desse polímero. Palavras-chave: degradação termocatalítica, polímeros, zeólita, método Flynn-Wall-Ozawa.

\section{INTRODUCTION}

Plastics are one of the most used materials due to their low-cost and good properties, such as lightweight, resistance, and energy efficiency, which provide their use in several industrial applications. The annual consumption of plastic in the world increases dramatically, with an estimated growth in global production of around $10 \%$ per year $[1,2]$. Despite the advantages offered by these materials, the progressive increase in their production causes several environmental problems due to the inadequate disposal of their residues, because they have a low-rate of biodegradability, owing to their chemical structure making them resistant to many

*brunojbarros@hotmail.com

Dhttps://orcid.org/0000-0002-0297-9588 natural degradation processes [3-5]. Conventional recycling provides limited applicability of recycled plastic waste and allows the emission of toxic compounds to the environment $[6,7]$. Given this, chemical treatments increasingly become an advantageous alternative route because they allow the processing of plastic waste, reducing the costs of pretreatment, collection, and selection. In addition, they allow the production of monomers or mixtures of hydrocarbons that serve as a raw material in refineries or petrochemical plants, from which products of high added value are obtained $[8,9]$. The main chemical treatment routes are thermal and catalytic degradation. Thermal degradation is a limited process, due to the need for high process temperatures (between 500 to $900{ }^{\circ} \mathrm{C}$ ) and low product selectivity. In contrast, catalytic degradation, with the use of a catalyst with suitable properties, promotes the reduction of the reaction temperature and restricts the selectivity of products $[10,11]$. 
Zeolitic materials are often used in the catalytic degradation of polymers, due to their excellent properties as catalysts, in addition to contributing to the resolution of the environmental problem generated by plastic waste. The zeolites combine high acidity with shape selectivity, high surface area, and high thermal stability [12, 13]. These particular properties promote the breaking of the $\mathrm{C}-\mathrm{C}$ bonds of the polymer chains and determine the products obtained [14, 15]. Different zeolitic structures (such as, beta, USY, ZSM-5, ZSM-12, ZSM-23) have been studied in the degradation of different polymers [16-19], with the difference in catalytic activity (number, strength, and distribution of acidic sites), specific area, size of particle, shape and pore size, the main factors that impact on the catalytic cracking of polymers [20, 21]. Thermogravimetric analysis (TG) is one of the most used techniques to evaluate the catalytic effect of zeolites on polymer decomposition. The information obtained allows us to study the kinetic data and the effect of polymer structure, composition, and operational variables on the pyrolysis process [22, 23]. Different methodologies, such as isoconversional model-fitting and model-free, are used to determine kinetic parameters from isothermal and nonisothermal TG data [24]. The Flynn-Wall-Ozawa method (FWO) is a well-known representative of model-free approaches, which allows estimating the activation energy values as a function of conversion without assuming a kinetic model [25-27].

In this context, the present work studied the thermocatalytic degradation of polyethylene (PE) and ultrahigh molecular weight polyethylene (UHMWPE) under different zeolitic catalysts (ZSM-5, ZSM-12, and ferrierite) with different pore systems (uni, bi, and threedimensional) and textural properties. The activation energy of the thermodegradation process was determined using the non-isothermal kinetic model proposed by Flynn-Wall-Ozawa.

\section{EXPERIMENTAL}

Catalysts. ZSM-5: this zeolite $\left(\mathrm{SiO}_{2} / \mathrm{Al}_{2} \mathrm{O}_{3}=56\right)$ in its cationic form was kindly supplied by Cenpes/Petrobras. To obtain its protonic form, the solid was subjected to an ion-exchange process (3 consecutive times) using an aqueous solution of $0.5 \mathrm{M}$ ammonium nitrate (SigmaAldrich, $95 \%$ ) at $80{ }^{\circ} \mathrm{C}$ for $2 \mathrm{~h}$. After the ion exchange, the zeolite was filtered and washed with distilled water until neutral $\mathrm{pH}$, then dried in an oven at $100{ }^{\circ} \mathrm{C}$ for $12 \mathrm{~h}$. Finally, $\mathrm{NH}_{4}-\mathrm{ZSM}-5$ was calcined at $550{ }^{\circ} \mathrm{C}$ for $6 \mathrm{~h}$ at a heating rate of $2^{\circ} \mathrm{C} \cdot \mathrm{min}^{-1}$ under an air flow of $100 \mathrm{~mL} \cdot \mathrm{min}^{-1}$. Ferrierite (FER): this zeolite (CP914C, Zeolyst) in the ammoniacal form $\left(\mathrm{NH}_{4}\right.$-FER) was obtained with ratio $\mathrm{SiO}_{2} / \mathrm{Al}_{2} \mathrm{O}_{3}=20$ and calcined under the same conditions as ZSM-5. ZSM-22: it was synthesized according to the molar composition of the gel and methodology described in [28] through the following steps: i) dissolution of $\mathrm{KOH}$ (Sigma-Aldrich, $85 \%$ ) in $30 \%$ of water; ii) solubilization of 1,6-diaminohexane (Sigma-Aldrich, 98\%) in 30\% of water; iii) dissolution of aluminum sulfate (Merck, 99\%) in $30 \%$ of water; and iv) dispersing colloidal silica (Ludox AS40, Sigma-Aldrich) in $10 \%$ of water. The synthesis gel was obtained by mixing the solutions of steps $\mathrm{i}$ and ii, followed by the addition of the solution obtained in step iii, and the dispersion of step iv. Each mixing step was mechanically agitated at $400 \mathrm{rpm}$ for $10 \mathrm{~min}$, except the last mixture that remained under the static condition for 30 min to obtain the synthesis gel with a molar composition of $27 \mathrm{NH}_{2}\left(\mathrm{CH}_{2}\right)_{6} \mathrm{NH}_{2}: 13.5 \mathrm{~K}_{2} \mathrm{O}: 1.0 \mathrm{Al}_{2} \mathrm{O}_{3}: 90 \mathrm{SiO}_{2}: 3600$ $\mathrm{H}_{2} \mathrm{O}$. The gel was transferred to a $700 \mathrm{~mL}$ Teflon vessel and inserted into a $1 \mathrm{~L}$ Parr 4520 stainless steel reactor. Crystallization was performed at $160{ }^{\circ} \mathrm{C}$ for $20 \mathrm{~h}$ under stirring at $400 \mathrm{rpm}$. The solid was recovered by filtration and washed with distilled water until the filtrate reached neutral $\mathrm{pH}$, then oven-dried at $100^{\circ} \mathrm{C}$ for $12 \mathrm{~h}$. The material was then calcined at $550{ }^{\circ} \mathrm{C}$ for $6 \mathrm{~h}$ and a heating rate of $2{ }^{\circ} \mathrm{C} \cdot \mathrm{min}^{-1}$ under $100 \mathrm{~mL} \cdot \mathrm{min}^{-1}$ air flow, and subsequently subjected to 3 consecutive ion exchanges using a $0.5 \mathrm{M}$ ammonium nitrate solution at $80{ }^{\circ} \mathrm{C}$ for $2 \mathrm{~h}$ in each step. Finally, the solid was washed, and calcined under the same conditions described previously.

Catalysts characterization: X-ray diffraction (XRD) analysis was performed in a Shimadzu XRD-6000 diffractometer, $\mathrm{CuK} \alpha(\lambda=0.1542 \mathrm{~nm}), \mathrm{Ni}$ filter, $40 \mathrm{kV}$ voltage, and $30 \mathrm{~mA}$ current. The data was collected in the $2 \theta$ range between $3^{\circ}$ and $40^{\circ}$, with a goniometer velocity of $2^{\circ} \cdot \mathrm{min}^{-1}$ and a step of $0.02^{\circ}$. Energy-dispersive X-ray spectrometry (EDX) was used to determine the $\mathrm{SiO}_{2} / \mathrm{Al}_{2} \mathrm{O}_{3}$ ratio in a Shimadzu EDX 7000/8000 spectrometer. Nitrogen adsorption-desorption measurements at $-196{ }^{\circ} \mathrm{C}$ were performed on a Micromeritics ASAP 2020 equipment in the $\mathrm{P} / \mathrm{P}_{0}$ range between 0.01 and 0.99 . Temperature programmed desorption of ammonia ( $\left.\mathrm{NH}_{3}-\mathrm{TPD}\right)$ profiles were determined in a SAMP3 Termolab multipurpose analytical system, where the samples were initially treated at $500{ }^{\circ} \mathrm{C}$ under a $30 \mathrm{~mL} \cdot \mathrm{min}^{-1}$ helium flow rate for $1 \mathrm{~h}$, then cooled to $100{ }^{\circ} \mathrm{C}$ and subjected to ammonia adsorption for $1 \mathrm{~h}$, followed by desorption in the temperature range of 100 to $800{ }^{\circ} \mathrm{C}$, with a heating rate of $10^{\circ} \mathrm{C} \cdot \mathrm{min}^{-1}$.

Thermo-catalytic degradation of the polymers: the polyethylene (PE, Aldrich, Mw 35000) and ultra-high molecular weight polyethylene (UHMWPE, Aldrich, Mw 3000000-6000000) were used in the study. The polymers were physically mixed with the catalysts in an agate mortar, in the weight proportion of $30 \%$ catalyst $70 \%$ polymer; this proportion was sufficient to evaluate the physicochemical properties of the catalyst in the degradation process, according to the saturating effects described in the literature [18]. The degradation experiments of the polymers were carried out in a thermobalance Shimadzu DTG-60H at a temperature range from room temperature to $600{ }^{\circ} \mathrm{C}$ under nitrogen flow of $50 \mathrm{~mL} \cdot \mathrm{min}^{-1}$ and heating rate of 5, 10, 20, and $30{ }^{\circ} \mathrm{C} \cdot \mathrm{min}^{-1}$. For each experiment, approximately 10 $\mathrm{mg}$ of the samples were used. The activation energy $\left(\mathrm{E}_{\mathrm{a}}\right)$ at different conversion values was determined by the Flynn- 
Wall-Ozawa method:

$$
\frac{d(\log \beta)}{d(1 / T)}=-0.4567 \cdot \frac{E_{a}}{R}
$$

where $\beta$ is the heating rate, $R$ is the ideal gas constant, and $T$ is the absolute temperature for the same conversion at each heating rate. The amount of coke (remaining residue on the catalyst after polymer degradation at $600{ }^{\circ} \mathrm{C}$ ) was estimated by [19]:

$$
\text { Coke }(\%)=\frac{\mathrm{M}_{\text {Final }}-\mathrm{M}_{\text {Cat }}}{\mathrm{M}_{\text {Cat }}} .100
$$

where $\mathrm{M}_{\text {Final }}$ is the final mass obtained at a temperature of $600{ }^{\circ} \mathrm{C}$, and $\mathrm{M}_{\text {Cat }}$ is the mass of fresh catalyst added to the polymer.

\section{RESULTS AND DISCUSSION}

Physicochemical properties of catalysts: the XRD patterns, nitrogen adsorption-desorption isotherms, and $\mathrm{NH}_{3}$-TPD profiles are shown in Fig. 1. All zeolites exhibited XRD patterns of highly crystalline materials, exhibiting all characteristic peaks for each structure described in the literature, ZSM-22 (JCPDS 38-197) [29], FER (JCPDS 44-0104) [30], and ZSM-5 (JCPDS 42-0023) [30]. The catalysts presented type I isotherms, exhibiting large amounts of $\mathrm{N}_{2}$ adsorbed in the range of $\mathrm{P} / \mathrm{P}_{0}<0.1$, and modest adsorption in the range of medium to high relative pressures, $\mathrm{P} / \mathrm{P}_{0}>0.1$, indicating the predominantly microporous nature of the zeolites [28, 31]. The $\mathrm{NH}_{3}$-TPD profiles indicated a similar behavior between the catalysts, demonstrating two main desorption events, being described as a typical profile of zeolitic materials [32]. The first peak (most intense) appeared in the low-temperature region between 100 and $350{ }^{\circ} \mathrm{C}$, attributed to weak Lewis and/or Brönsted acid sites. The second peak (less intense) occurred above $350{ }^{\circ} \mathrm{C}$, related to strong Brönsted acid sites [33].

The results of the EDX, $\mathrm{N}_{2}$ adsorption-desorption, and $\mathrm{NH}_{3}$-TPD are summarized in Table I. The EDX measurements corroborated the $\mathrm{SiO}_{2} / \mathrm{Al}_{2} \mathrm{O}_{3}$ ratio values provided by Cenpes/Petrobras (ZSM-5) and Zeolyst (FER), and in the case of ZSM-22, it was observed that after crystallization of the zeolite, the $\mathrm{SiO}_{2} / \mathrm{Al}_{2} \mathrm{O}_{3}$ ratio value was very close to the theoretical ratio (90), indicating that most of the aluminum was incorporated into the zeolitic structure. The results obtained from the $\mathrm{N}_{2}$ adsorption-desorption measurements showed that the ZSM-22 presented the lowest values of area and pore volume due to the one-dimensional pore system and medium pore size (4.6x5.7 $\AA$ ) [34], FER demonstrated intermediate values, since it is a medium
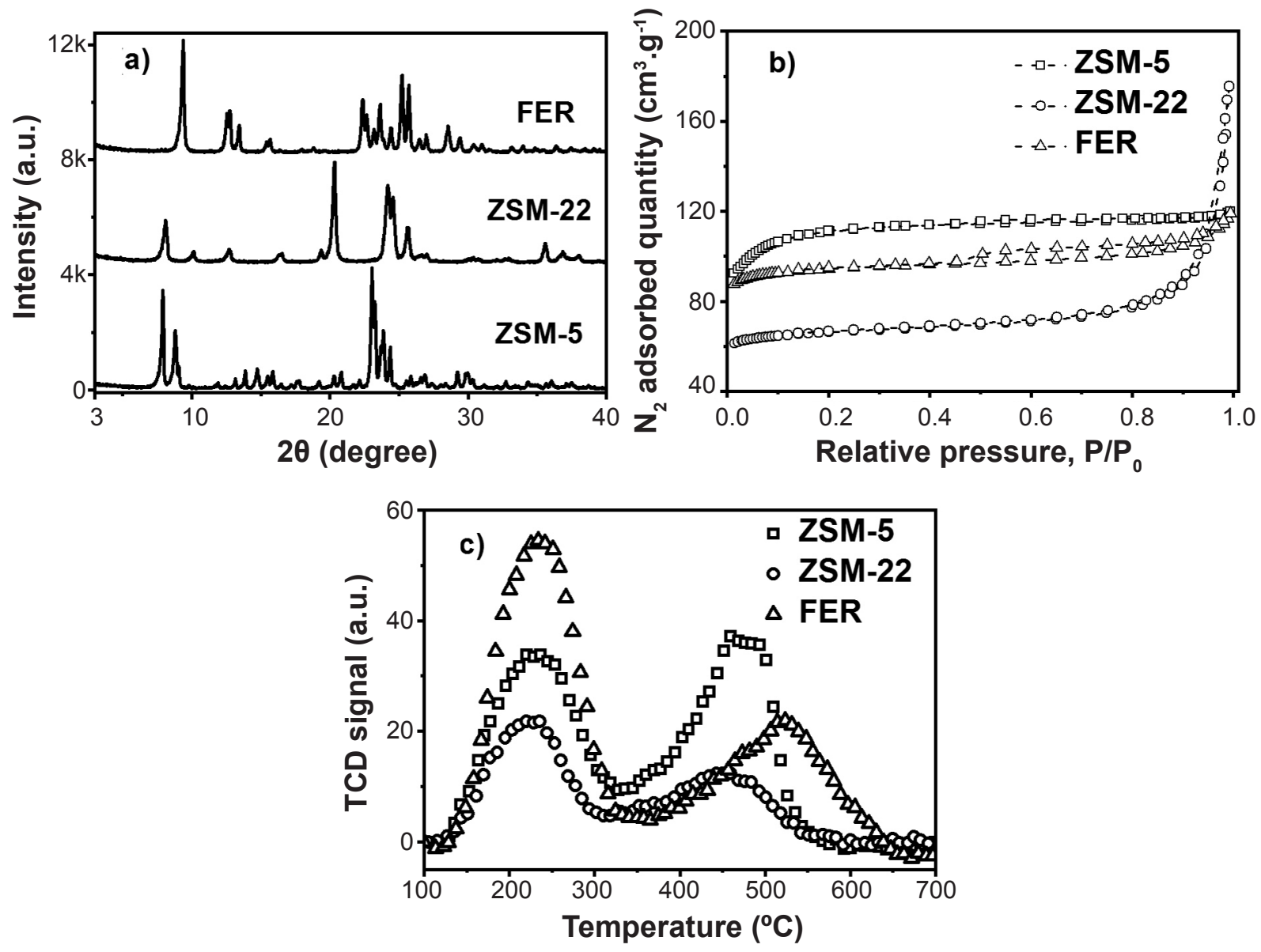

Figure 1: XRD patterns (a), $\mathrm{N}_{2}$ adsorption-desorption isotherms (b), and $\mathrm{NH}_{3}$-TPD profiles (c) of zeolites.

[Figura 1: Padrões de DRX (a), isotermas de adsorção-dessorção de $\mathrm{N}_{2}(b)$ e perfis de TPD-NH $\mathrm{N}_{3}(c)$ das zeólitas.] 
Table I - Results of the EDX, $\mathrm{N}_{2}$ adsorption-desorption, and $\mathrm{NH}_{3}$-TPD.

[Tabela I - Resultados de EDX, adsorção-dessorção de $\mathrm{N}_{2}$ e TPD-NH $\mathrm{N}_{3}$.]

\begin{tabular}{ccccccc}
\hline Sample & $\begin{array}{c}\mathrm{Si} / \mathrm{Al} \\
\text { ratio }^{\mathrm{a}}\end{array}$ & $\begin{array}{c}\mathrm{S}_{\mathrm{BET}}^{\mathrm{b}} \\
\left(\mathrm{m}^{2} \cdot \mathrm{g}^{-1}\right)\end{array}$ & $\begin{array}{c}\mathrm{S}_{\mathrm{Mic}}{ }^{\mathrm{c}} \\
\left(\mathrm{m}^{2} \cdot \mathrm{g}^{-1}\right)\end{array}$ & $\begin{array}{c}\mathrm{S}_{\mathrm{Ext}}{ }^{\mathrm{d}} \\
\left(\mathrm{m}^{2} \cdot \mathrm{g}^{-1}\right)\end{array}$ & $\begin{array}{c}\mathrm{V}_{\mathrm{Mic}}{ }^{\mathrm{e}} \\
\left(\mathrm{cm}^{3} \cdot \mathrm{g}^{-1}\right)\end{array}$ & $\begin{array}{c}\mathrm{NH}_{3} \text {-TPD total } \\
\text { acidity }\left(\mu \mathrm{mol}_{\mathrm{g}} \mathrm{g}^{-1}\right)\end{array}$ \\
\hline ZSM-22 & 76 & 251 & 217 & 34 & 0.09 & 415 \\
FER & 20 & 359 & 322 & 37 & 0.13 & 1264 \\
ZSM-5 & 56 & 422 & 336 & 86 & 0.13 & 901 \\
\hline
\end{tabular}

${ }^{a}$ measured by energy-dispersive $X$-ray spectroscopy $(E D X) ;{ }^{b}$ BET surface area; ${ }^{c}$ microporous area $;{ }^{d}$ external area $\left(S_{B E T}-S_{\text {Mic }}\right) ;{ }^{e}$ micropore volume.

pore zeolite having two-dimensional pore system $(5.4 \times 4.2$, $3.5 \times 4.8 \AA$ ) [34], and ZSM-5 denoted the highest values, due to having a three-dimensional pore system and largest pores $(5.1 \times 5.5,5.3 \times 5.6 \AA)$ [35]. The results of the $\mathrm{NH}_{3}$ TPD confirmed the values of $\mathrm{Si} / \mathrm{Al}$ ratio obtained by EDX, since the acidity is proportional to the amount of $\mathrm{Al}$ of the zeolite [36], obtaining the following order of concentration or density of acidic sites: FER>ZSM-5>ZSM-22.

Thermo-catalytic degradation of polymers: the thermogravimetric curves for catalytic thermodegradation of the PE and UHMWPE under a heating rate of $10^{\circ} \mathrm{C} \cdot \mathrm{min}^{-1}$ are shown in Fig. 2. Thermogravimetric curves showed events of mass loss corresponding to the cracking of the polymers, associated with the evaporation or volatilization of lighter products, indicating that the degradation of pure polymers and with catalysts happened in a single stage of mass loss. Another important characteristic observed was that the addition of the catalysts substantially decreased the degradation temperature range of the polymers. There are reports in the literature $[23,37]$ showing that, during the thermo-catalytic degradation process, the polymer melts and spreads between the interparticle spaces of the zeolites, dispersing around the outer surface and active sites of the catalysts. The polymeric macromolecules are cracked on the catalyst external surface, producing low molecular weight compounds, which diffuse through the polymer film as a product or react further into the pores. Reactions continue via carbocation as a transition state, which is governed by both the nature of the formed carbocation and the nature and strength of the acidic sites. On the other hand, in thermal
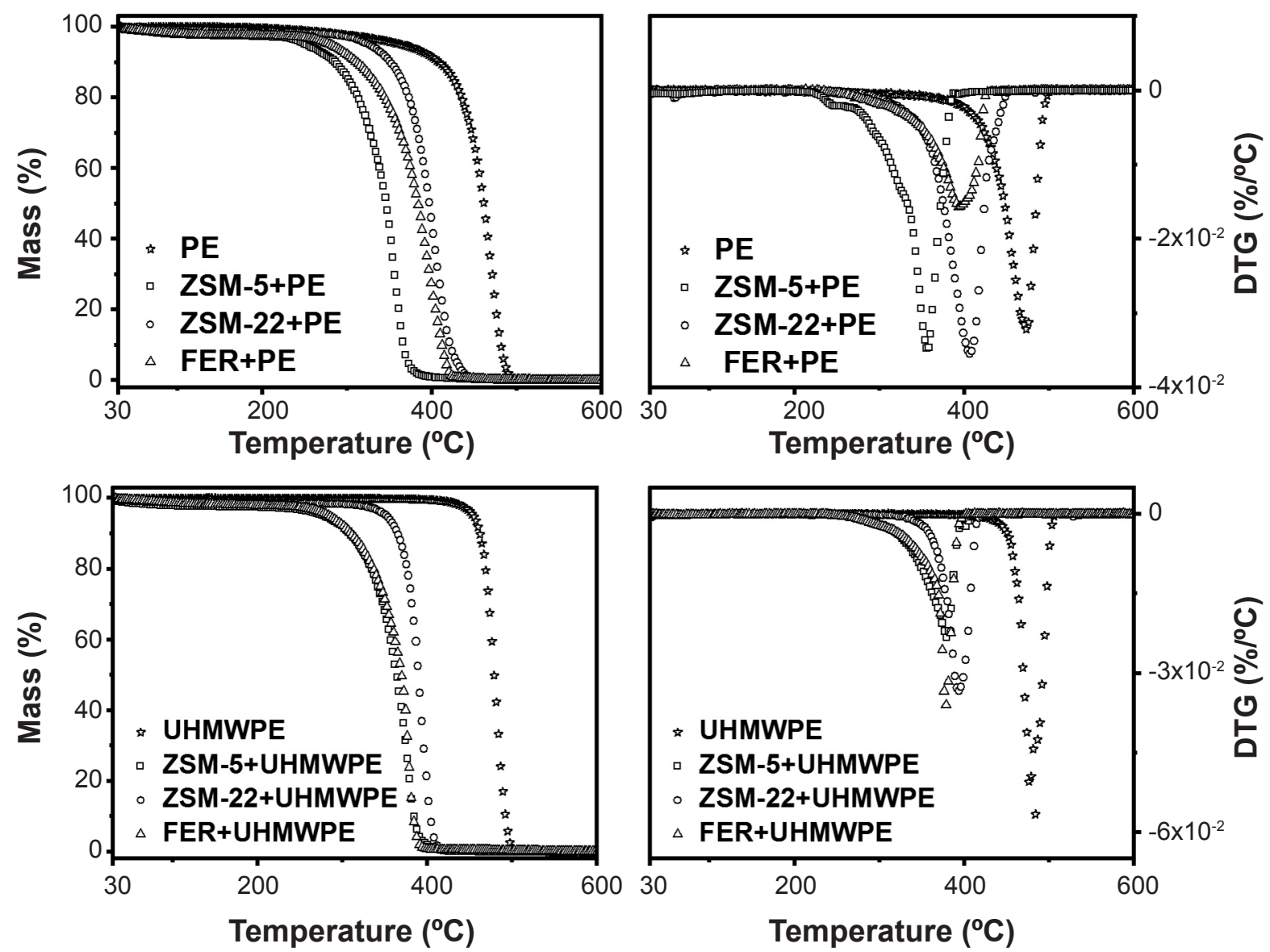

Figure 2: TG/DTG curves of the catalytic thermodegradation process of the PE and UHMWPE under a heating rate of $10{ }^{\circ} \mathrm{C} . \mathrm{min}^{-1}$. [Figura 2: Curvas de TG/DTG do processo de termodegradação catalítica do PE e UHMWPE sob taxa de aquecimento de $10^{\circ} \mathrm{C}$.min ${ }^{-1}$.] 
Table II - Thermogravimetric parameters obtained in the catalytic thermodegradation of the polymers, under a heating rate of $10^{\circ} \mathrm{C} \cdot \mathrm{min}^{-1}$.

[Tabela II - Parâmetros termogravimétricos obtidos na termodegradação catalítica dos polímeros em taxa de aquecimento de $10^{\circ} \mathrm{C} . \mathrm{min}^{-1}$.]

\begin{tabular}{ccccc}
\hline Sample & $\mathrm{T}_{\text {Initial }}{ }^{\mathrm{a}}\left({ }^{\circ} \mathrm{C}\right)$ & $\mathrm{T}_{\text {Final }}{ }^{\circ}\left({ }^{\circ} \mathrm{C}\right)$ & ${\text { Mass } \operatorname{loss}^{\mathrm{b}}(\operatorname{mass} \%)}$ Coke $^{\mathrm{c}}(\operatorname{mass} \%)$ \\
\hline PE & 360 & 504 & 99.96 & 0.04 \\
ZSM-5+PE & 225 & 403 & 98.9 & 1.1 \\
ZSM-22+PE & 291 & 459 & 94.1 & 5.9 \\
FER+PE & 256 & 433 & 95.7 & 4.3 \\
UHMWPE & 426 & 512 & 100.0 & 0.0 \\
ZSM-5+UHMWPE & 259 & 417 & 95.4 & 4.6 \\
ZSM-22+UHMWPE & 322 & 426 & 97.2 & 2.8 \\
FER+UHMWPE & 256 & 406 & 94.4 & 5.6 \\
\hline
\end{tabular}

${ }^{a}$ obtained from DTG curve; ${ }^{b}$ until $520{ }^{\circ} \mathrm{C}$; ${ }^{c}$ calculated by Eq. B.

degradation, only one reaction mechanism occurs, while the presence of active sites on the catalyst surface provides broad possibilities of reaction mechanisms [38].

Table II shows the thermogravimetric parameters obtained in the catalytic thermodegradation of the $\mathrm{PE}$ and UHMWPE, under a heating rate of $10{ }^{\circ} \mathrm{C} \cdot \mathrm{min}^{-1}$. The zeolites caused the effects of decomposition, considerably reducing the initial and final temperatures of polymer degradation. Comparing the zeolites, it was observed that the zeolitic structures with larger pore diameter and three and bi-dimensional channel systems (ZSM-5 and FER) supplied the lowest values of initial and final temperature in the degradation of both polymers. FER zeolite showed to be more effective in reducing UHMWPE degradation temperatures in comparison to ZSM-5, although FER had lower values of the surface area and micropore volume; this effect can be attributed to the fact this zeolite has a more expressive acidity, revealing a synergy between accessibility and acidity in the degradation of longer chain polymer. The amount of coke formed on the zeolitic structures during the degradation of PE demonstrated the tendency that the larger the pore opening the smaller the amount of coke formed (ZSM-5<FER<ZSM-22); in contrast to the degradation of UHMWPE, acidity was the most imperative factor, with the most acidic catalyst showing the higher coke deposit (FER $>$ ZSM-5>ZSM-22).

Another important parameter obtained from the DTG (derivative TG) curves was the maximum degradation temperatures $\left(\mathrm{T}_{\text {Max }}\right)$, which are shown in Table III. The results showed that the addition of the zeolites to the polymer promoted a significant reduction in the polymer degradation $\mathrm{T}_{\text {Max }}$ values at the different heating rates studied, showing the effectiveness of the catalysts. DTG peak temperatures were also shifted to lower temperatures depending on the activity of the catalysts. The increase in temperature for different rates can be explained by the increase in the amount of energy supplied in the heat form, for the same increment of time [39]. Conversion values at the temperature of maximum degradation rate, $\alpha_{\text {Max }}$, are listed in Table IV for all heating rates employed. Generally, this value is accepted as the decisive parameter to distinguish the reaction model for kinetic studies [40, 41]. We used it here to compare how the reaction rate differs over the zeolites during the degradation. The conversion of PE and UHMWPE at the temperature of the maximum degradation rate was between 0.55 to 0.75 and 0.61 to 0.71 , respectively, for self-degradation without catalysts. In the degradation of PE, all the catalysts presented the increase of the maximum conversion values, indicating a relative ease diffusion of the smaller polyethylene fragments to access the active sites inside the zeolite pores; the opposite was observed in the case of UHMWPE, possibly the large macromolecules of this polymer reacted more slowly on the surface of zeolites, becoming a limiting factor.

Fig. 3 displays the values of activation energy as a function of the conversion for the degradation process of pure polymers and with catalysts. The addition of zeolites to polymers significantly reduced the energy level required

Table III - Thermogravimetric parameter values obtained in the catalytic thermodegradation of polymers under different heating rate $(\beta)$.

[Tabela III - Valores do parâmetro termogravimétrico obtidos na termodegradação catalítica dos polímeros em diferentes taxas de aquecimento $(\beta)$.]

\begin{tabular}{ccccc}
\hline \multirow{2}{*}{ Sample } & \multicolumn{4}{c}{$\left.\mathrm{T}_{\mathrm{Max}}{ }^{\mathrm{a}}{ }^{\circ} \mathrm{C}\right)$} \\
\hline PE & 457 & 473 & 482 & 485 \\
ZSM-5+PE & 346 & 359 & 382 & 394 \\
ZSM-22+PE & 382 & 405 & 435 & 450 \\
FER+PE & 387 & 395 & 411 & 423 \\
UHMWPE & 471 & 484 & 497 & 505 \\
ZSM-5+UHMWPE & 363 & 381 & 396 & 409 \\
ZSM-22+UHMWPE & 381 & 393 & 409 & 423 \\
FER+UHMWPE & 364 & 378 & 394 & 431 \\
\hline$a_{\text {obtained from } D T G \text { curve }}$ & & & &
\end{tabular}


Table IV - Conversion values of the samples at maximum degradation rates $\left(\alpha_{\mathrm{Max}}\right)$.

[Tabela IV - Valores de conversão das amostras em taxas máximas de degradação $\left(\alpha_{M a x}\right)$.]

\begin{tabular}{ccccc}
\hline \multirow{2}{*}{ Sample } & \multicolumn{4}{c}{ Heating rate, $\beta\left({ }^{\circ} \mathrm{C} \cdot \mathrm{min}^{-1}\right)$} \\
& $\beta=5$ & $\beta=10$ & $\beta=20$ & $\beta=30$ \\
\hline PE $^{\mathrm{a}}$ & 0.750 & 0.732 & 0.638 & 0.556 \\
ZSM-5+PE & 0.715 & 0.727 & 0.768 & 0.788 \\
ZSM-22+PE & 0.617 & 0.648 & 0.685 & 0.719 \\
FER+PE & 0.652 & 0.678 & 0.680 & 0.721 \\
UHMWPE & 0.716 & 0.707 & 0.622 & 0.616 \\
ZSM-5+UHMWPE & 0.826 & 0.778 & 0.768 & 0.538 \\
ZSM-22+UHMWPE & 0.640 & 0.637 & 0.606 & 0.601 \\
FER+UHMWPE & 0.784 & 0.726 & 0.675 & 0.527 \\
\hline
\end{tabular}

${ }^{a}$ self-degradation without a catalyst.

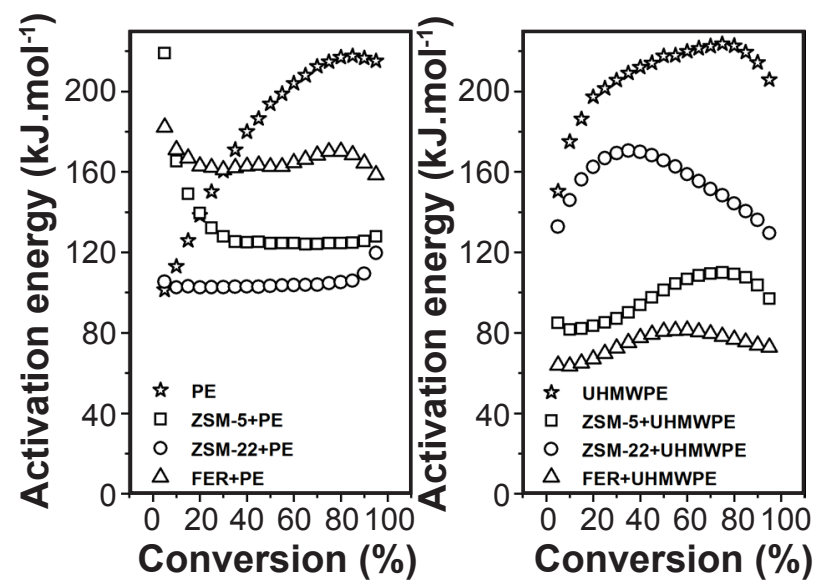

Figure 3: Activation energy versus conversion of the polymer catalytic thermodegradation.

[Figura 3: Energia de ativação versus conversão da termodegradação catalítica dos polímeros.]

for the polymeric degradation. The ZSM-22 zeolite showed the lowest activation energy value in relation to the other structures in the PE thermocatalytic degradation, where the following average energy order $\left(\mathrm{E}_{\text {am }}\right)$ was obtained: ZSM$22\left(\mathrm{E}_{\mathrm{am}}=105 \mathrm{~kJ} \cdot \mathrm{mol}^{-1}\right)<\mathrm{ZSM}-5 \quad\left(\mathrm{E}_{\mathrm{am}}=135 \mathrm{~kJ} \cdot \mathrm{mol}^{-1}\right)<\mathrm{FER}$ $\left(\mathrm{E}_{\mathrm{am}}=166 \mathrm{~kJ} \cdot \mathrm{mol}^{-1}\right)<$ pure PE $\left(\mathrm{E}_{\mathrm{am}}=180 \mathrm{~kJ} \cdot \mathrm{mol}^{-1}\right)$. Although ZSM-5 had higher acidity, three-dimensional structure, and larger pore opening, this fact was possibly due to the ZSM-22 zeolite has a one-dimensional pore structure and, even more importantly, crystallite size around $32 \mathrm{~nm}$ [34], lower than that reported for FER (36 nm) [38] and ZSM-5 (between 50 to $100 \mathrm{~nm}$ ) [42], providing a shorter diffusional path to polymer fragments and for products formed. In the UHMWPE degradation, there was a simultaneous effect of accessibility of the macromolecules and acidity, with FER zeolite demonstrating to be more effective in degrading this polymer. The order of the average of the obtained energies was: FER $\left(\mathrm{E}_{\mathrm{am}}=74 \mathrm{~kJ} \cdot \mathrm{mol}^{-1}\right)<Z \mathrm{ZSM}-5\left(\mathrm{E}_{\mathrm{am}}=97 \mathrm{~kJ} \cdot \mathrm{mol}^{-1}\right)<\mathrm{ZSM}-22$
$\left(\mathrm{E}_{\mathrm{am}}=155 \mathrm{~kJ} \cdot \mathrm{mol}^{-1}\right)<$ pure UHMWPE $\left(\mathrm{E}_{\mathrm{am}}=207 \mathrm{~kJ} \cdot \mathrm{mol}^{-1}\right)$.

\section{CONCLUSIONS}

The characterization techniques showed that all zeolites had a significant degree of crystallinity, with distinct zeolitic channels systems, area, and pore volume values in agreement with the literature, where the highest values were for the ZSM-5 zeolite with three-dimensional channel system. In terms of surface acidity, ferrierite showed higher total acidity, followed by ZSM-5 and ZSM-22. The study of the addition of zeolites of different properties (composition, pore system, and acidity) as a catalyst for the degradation reactions of PE and UHMWPE polymers made it possible to establish that the addition of catalysts substantially decreases the degradation reaction temperature range of the polymers, regardless of the heating rate used in the thermogravimetric degradation experiments. Considering the relationship between the properties of the zeolites and their catalytic performance, it was observed that the zeolitic structures with larger pore diameter and bi and three-dimensional channel systems (FER and ZSM-5) resulted in the lowest values of initial and final temperatures for the degradation process of both polymers. The presence of catalysts in the polymer degradation process seems to reduce the level of energy required for cracking reactions. In the case of polyethylene (PE), the ZSM-22 zeolite showed the lowest average activation energy $\left(\mathrm{E}_{\mathrm{am}}\right)$ compared to the other zeolites evaluated, with $\mathrm{E}_{\mathrm{am}}=105,135$, and $166 \mathrm{~kJ}^{\mathrm{mol}}{ }^{-1}$ for ZSM22, ZSM-5, and FER, respectively. These values were much lower than that measured for the thermal degradation of pure $\mathrm{PE}$, which was on the order of $180 \mathrm{~kJ}^{\mathrm{mol}}{ }^{-1}$. In the case of UHMWPE, the effectiveness of the added catalyst appears to result from a combined effect of the accessibility to the active sites of the polymer molecules and the level of acidity of the catalyst. FER zeolite exhibited the highest activity for degradation reactions when compared to other catalysts and pure polymer. In this system, the order of $\mathrm{E}_{\mathrm{am}}$ values was: FER $\left(\mathrm{E}_{\mathrm{am}}=74 \mathrm{~kJ} \cdot \mathrm{mol}^{-1}\right)<\mathrm{ZSM}-5\left(\mathrm{E}_{\mathrm{am}}=97 \mathrm{~kJ} \cdot \mathrm{mol}^{-1}\right)<\mathrm{ZSM}-22$ $\left(\mathrm{E}_{\mathrm{am}}=155 \mathrm{~kJ} \cdot \mathrm{mol}^{-1}\right)<$ pure UHMWPE $\left(\mathrm{E}_{\mathrm{am}}=207 \mathrm{~kJ} \cdot \mathrm{mol}^{-1}\right)$.

\section{ACKNOWLEDGMENTS}

The authors are grateful for the financial support of the Coordenação de Aperfeiçoamento de Pessoal de Nível Superior (CAPES), through a research grant and to CENPES/PETROBRAS and ANP for the financial support.

\section{REFERENCES}

[1] D. Almeida, M.F. Marques, Polímeros 26, 1 (2016) 44. [2] M.F. Ali, S. Ahmed, M.S. Qureshi, Fuel Process. Technol. 92, 5 (2011) 1109.

[3] A. Rapacz-Kmita, M. Gajek, M. Dudek, E. StodolakZych, B. Szaraniec, R. Lach, J. Therm. Anal. Calorim. 127 (2017) 389.

[4] E. Valanciene, L. Miknius, N. Pedisius, J. Therm. Anal. 
Calorim. 124 (2016) 341.

[5] R. Geyer, J.R. Jambeck, K.L. Law, Sci. Adv. 3 (2017) 1700 .

[6] M.L.M. Valle, M.J.O.C. Guimarães, C.M.S. Sampaio, Polímeros 14, 1 (2004) 17.

[7] S.H. Shah, Z.M. Khan, I.A. Raja, Q. Mahmood, Z.A. Bhatti, J. Khan, A. Farooq, N. Rashid, D. Wu, J. Hazard Mater. 179, 1-3 (2010) 15.

[8] F. Vidal, R.R. Gowda, E.Y.X. Che, J. Am. Chem. Soc. 137, 29 (2015) 9469.

[9] C. Ma, J. Yu, B. Wang, Z. Song, J. Xiang, S. Hu, S. Su, L. Sun, Renew. Sust. Energ. Rev. 61 (2016) 433.

[10] H. Ohkita, R. Nishiyama, Y. Tochihara, T. Mizushima, N. Kakuta, Y. Morioka, A. Ueno, Y. Namiki, S. Tanifuji, H. Katoh, H. Sunazyka, R. Nakayama, T. Kuroyanagi, Ind. Eng. Chem. Res. 32, 12 (1993) 3112.

[11] T. Isoda, T. Nakahara, K. Kusakabe, S. Morooka, Energy Fuels 12, 6 (1998) 1161.

[12] A. Marcilla, A. Gómez-Siurana, D. Berenguer, Appl. Catal. A Gen. 301, 2 (2006) 222.

[13] V.J. Fernandes Jr., A.S. Araujo, R.A. Medeiros, J.R. Matos, L.P. Mercuri, A.O. Silva, D.M.A. Melo, J. Therm. Anal. Calorim. 56 (1999) 1279.

[14] A. López, I. De Marco, B.M. Caballero, A. Adrados, M.F. Laresgoiti, J. Waste Manag. 31, 8 (2011) 1852.

[15] D.P. Serrano, J. Aguado, J.M. Escola, J.M. Rodríguez, J. Anal. Appl. Pyrol. 74, 1-2 (2005) 353.

[16] A. Marcilla, A. Gómez-Siurana, F. Valdés, J. Anal. Appl. Pyrol. 79, 1-2 (2007) 433.

[17] G. Manos, A. Garforth, J. Dwyer, Ind. Eng. Chem. Res. 39 (2000) 1203.

[18] A.O.S. Silva, M.J.B. Souza, A.M.G. Pedrosa, A.C.F. Coriolano, V.J. Fernandes Jr., A.S. Araujo, Micropor. Mesopor. Mater. 244 (2017) 1.

[19] B.J.B. Silva, L.V. Sousa, L.R.A. Sarmento, S.L.Alencar, P.H.L. Quintela, A.O.S. Silva, Appl. Catal. B Environ. 267 (2020) 118699.

[20] X. Li, B. Shen, Q. Guo, J. Gao, Catal. Today 125, 3-4 (2007) 270.

[21] W. Kaminsky, I.-J. N. Zorriqueta, J. Anal. Appl. Pyrol. 79, 1-2 (2007) 368.
[22] A. Durmuş, S. Koç, G. Pozan, Z. Kaşgöz, Appl. Catal. B Environ. 61, 3-4 (2005) 316.

[23] A. Marcilla, M.I. Beltrán, R. Navarro, J. Anal. Appl. Pyrol. 76, 1-2 (2006) 222.

[24] J.H. Flynn, Thermochim. Acta 300, 1-2 (1997) 83.

[25] T. Ozawa, Bull. Chem. Soc. Jpn. 38, 11 (1965) 1881.

[26] T. Ozawa, Bull. Chem. Soc. Jpn. 39, 10 (1966) 2071.

[27] J. Flynn, L. Wall, J. Res. Nat. Bur. Stand. 70, 6 (1966) 487.

[28] B.J.B. Silva, L.V. Sousa, P.H.L. Quintela, N.R. Alencar Júnior, S.L. Alencar, P.A.M. Maciel, J.R. Santos, L.R.A. Sarmento, S.M.P. Meneghetti, A.O.S. Silva, Mater. Lett. 218 (2018) 119.

[29] A.R. Loiola, J.C.R. de A. Andrade, J.M. Sasaki, L.R.D. da Silva, E.J. Nassar, Cerâmica 56, 339 (2010) 250.

[30] B.J.B. Silva, A.O.S. Silva, P.P.M. Neto, T.P.M. Costa, L.V.S. Júnior, L.M.O. Ribeiro, S.L. Alencar, A.E. Silva, R.B. Santos, Cerâmica 61, 357 (2015) 14.

[31] S. Zhang, X. Liu, Y. Zhang, T. Lv, J. Zheng, W. Gao, X. Liu, M. Cui, C. Meng, RSC Adv. 115 (2016) 114808.

[32] N. Katada, H. Igi, J.H. Kim, M. Niwa, J. Phys. Chem. B 101, 31 (1997) 5969.

[33] H.G. Karge, Stud. Surf. Sci. Catal. 65 (1991) 133.

[34] M. Tiitta, E. Harlin, J. Makkonen, A. Root, F. Sandelin, H. Österholm, Stud. Surf. Sci. Catal. 154 (2004) 2323.

[35] J.G. Bendoraitis, A.W. Chester, F.G. Dwyer, W.E. Garwood, Stud. Surf. Sci. Catal. 28 (1986) 669.

[36] D. Barthomeuf, Mater. Chem. Phys. 17, 1-2 (1987) 49.

[37] F. Pinto, P. Costa, I. Gulyurtlu, I. Cabrita, J. Anal. Appl. Pyrol. 5, 1-2 (1999) 57.

[38] A. Ishihara, K. Inui, T. Hashimoto, H. Nasu, J. Catal. 295 (2012) 81.

[39] V. Caldeira, A. Santos, D. Oliveira, R. Lima, L. Souza, S. Pergher, J. Therm. Anal. Calorim. 130 (2017) 1939.

[40] Z. Gao, I. Amasaki, M. Nakada, Thermochim. Acta 385, 1-2 (2002) 95.

[41] F. Lee, D. Dollimore, Thermochim. Acta 323, 1-2 (1998) 75.

[42] A.E. Persson, B.J. Schoeman, J. Sterte, J.E. Otterstedt, Zeolite 15, 7 (1995) 611.

(Rec. 29/02/2020, Rev. 23/04/2020, Ac. 11/05/2020) 